\title{
The barriers of educational inclusion of children with disabilities in the elementary education in the Republic of Macedonia
}

Popovska Nalevska, Gorica

Internacional Slavic University, Gavrilo Romanovic Derzavin, Republic of Macedonia (popovska.g@gmail.com)

Popovski, Filip $\unrhd$

Faculty of technical sciences, St. Kliment Ohridski University - Bitola, Republic of Macedonia (Filip.popovski@tfb.uklo.edu.mk)

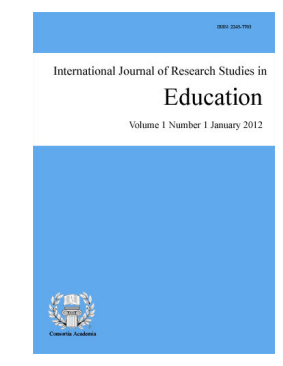

ISSN: 2243-7703 Online ISSN: 2243-7711

OPEN ACCESS

\section{Abstract}

A flexible environment that responds to students' needs is the basis for involving marginalized groups, such as children with disabilities, in the existing educational system. The right of education is a right of all children, including the ones with disabilities; a right that is guaranteed by all countries that have signed the Convention on the Rights of the Child, including Republic of Macedonia. Inclusive education is a matter of human rights, but also a matter of good organization and resource management - management of human resources, materials, and time. However, few countries have formulated a clear policy for children with disabilities. The start of inclusive education requires changes in the curriculum, further education for the teachers, and developed teaching methodology and attitudes of the teachers. This paper presents the results of the research conducted in order to detect the factors that are consider to be barriers for quality educational inclusion of students with disabilities in the elementary schools in the Republic of Macedonia, by examining the attitudes and opinions of all participants who are, in any way, involved in the educational process - parents, teachers, and pedagogical - psychological services, from ten primary schools in the Republic of Macedonia and representatives from the Ministry of Education and Science and the Bureau for Development of Education. The findings of this study enabled to present some recommendation and implications that might be useful for policy makers, teachers, and educational researchers.

Keywords: inclusive education; students with disabilities; teachers; barriers for inclusive education; elementary school 


\section{The barriers of educational inclusion of children with disabilities in the elementary education in the Republic of Macedonia}

\section{Introduction}

One of the priorities in the reform of the education system is the creation of an inclusive education that will be in function of the student and his developmental and educational needs. Inclusive education means quality education for all and fits into policies for absolute inclusion in schools. This also involves adapting the teaching of the educational needs of children, including those children who have difficulty fitting into the existing education system.

The school as a social environment should be an environment suitable for learning and living; an environment open to the community and in which learning is an integral part of life. The inclusion in education is an opportunity for education reforms to focus their attention on creating schools that will meet the needs of all students and the society as a whole; the focus of inclusion is the necessity of adapting schools to the educational needs of the student (Bartolo, 2004). Such schools include diversity and contribute to developing each individual as a person who critically assesses and draws conclusions, and builds his attitudes and beliefs. Such organized schools not only support inclusion, but individualism over collectivism by liberating the human capacities that are necessary in the building of a democratic society.

Educational inclusion is an opportunity for exceeding approach in education reforms. It is primarily a pedagogical, and not a defectology challenge, with the necessary involvement of a great number of experts from different areas necessary for supporting children, especially children with disabilities, in order to maximize their opportunities in the process of upbringing and educating. Learning is most effective in an environment that has interpersonal relationships and interactions, and in an environment in which a student feels respected and recognized (Lambert \& McCombs, 1998). It is precisely this that is its essence - how the traditional schools are developed in a way that suits the educational and social needs of each student, and they are shaped to be a place where every student belongs, where each and every student is accepted and supported by his classmates and all other members of the school community (Steinbeck, 1952). However, the adaptation of schools to the diversity of students is only possible with radical changes in the educational system. Achieving inclusion cannot be done without a cultural reconstruction of the school system (Armstrong, 2003), referring to the reconstruction of the pre-existing culture, educational policies and educational practices, so that they respond to the students with special needs.

What is actually needed is change in the principles of the education system: the schools must be transformed from schools with competitive nature to schools that will apply the individual approach - schools customized to "human nature". Only such a reform can provide a formidable future to students, as well as a formidable future to the society, in general.

\subsection{Significance of the Study}

The implementation of inclusive education in Republic of Macedonia brings many challenges. Inclusion is a process by which schools, local education authorities and others develop cultures, policies and practices to include students. The purpose of this study is to determine the factors that represent a significant barrier for quality inclusive education, to gave some recommendations for their reduction and to encourage new research and initiatives for improving the conditions for inclusive education of children with disabilities in the Republic of Macedonia. The recommendations given in the study should encourage teachers what they can make it in existing conditions in order to improve the quality of educational inclusion. 
Barriers of educational inclusion of children with disabilities in the elementary education in Macedonia

With the right training, strategies and support nearly all children with special educational needs can be successfully included in mainstream education. Education is a continuous process and in parallel with the inclusion process, it is necessary to develop adequate services that will provide a team approach in resolving problems in the regular school.

\section{Results from previous research in Republic of Macedonia}

The Republic of Macedonia is a signatory country of several significant international documents that serve as basis for the principles of inclusive education:

$>\quad$ Universal Declaration of Human Rights from 10 December, 1948.

D Convention on the Rights of the Child (ratified by the Republic of Macedonia in 1993).

> Convention on the Rights of Persons with Disabilities (ratified by the Republic of Macedonia in December 2011).

> National Program for the Development of Education in the Republic of Macedonia 2005-2015 (Primary and secondary education is open and provides access for all children regardless of language, sex, religion or physical and mental disability).

It is certain that the education of children with disabilities in the Republic of Macedonia does not rely on a long tradition. During the development period of sixty years, the following activities have been undertaken:

$>$ regulation of a flexible system of upbringing and education;

$>$ formation of a network of institutions that meets the existing needs;

$>\quad$ set up of a funding system;

$>$ mandatory team review from appropriate expert commissions for each child before referral to an appropriate institution;

$>$ educational process that is being carried out according to curricula and programs that contain specificities, that do not alter the already existing, general educational goals.

The current system of education for children with special educational needs in Republic of Macedonia is organized in three basic forms: education in special schools, special classes in regular schools and in regular (inclusive) schools. Children with special educational needs attend special education schools or regular elementary schools, to which they are referred by recommendation of the Commission for classification which assesses the degree and type of disability.

The previous decade in Macedonia was marked by an effort to introduce social and educational inclusion of people/children with special educational needs. It was initially introduced through independent pilot projects supported either by the Government (Ministry of Education and the Ministry of Social Policy) or by largest organizations for children's rights (UNICEF) in cooperation with relevant ministries, educational institutions and local non-governmental organizations. Unified monitoring of inclusive education and data of children with special education needs does not exist, but there are some available data within international projects and previous researches.

The National Deinstitutionalization Strategy of the system for social protection of the Republic of Macedonia (2007), explicitly requests the Ministry of Education and Science to create conditions for inclusion of children with special educational needs in special and regular schools. In order to achieve this goal, the National Program for the Development of Education (2005-2015) calls for increasing emphasis on the training of teachers for providing education for children with disabilities. The European Training Forum (2009) noted that there are 
very few opportunities at faculty for teachers for educating teachers for work with children with disabilities. According to the ETF, there is one subject that is called Inclusive education, but that is an optional subject.

In his study Ombudsman of the Republic of Macedonia (2016), claims:

D The legislation and some relevant bylaws in the Republic of Macedonia, as regards the education of children with disabilities, is not in accordance with the international standards given in the Convention on the Rights of the Child and the Convention on the Rights of Persons with Disabilities.

$>$ The legislation in the Republic of Macedonia is focused more on the disability of the children as a medical category and to addressing the problems arising from it, rather than towards the potential of the children and their abilities. There is no education system which is subordinated to diversity and the needs of every child (reasonable accommodation), so that the children are categorized and enrolled in educational institutions according to those categorizations. The medical categorization of the children remains to be the way for the child to go forward through the education system, both in conditions of special schools (which are associated with a specific type of disability) and special classes in regular schools (which are also associated with the medical categorization), and this is not a single education system at all.

$>$ The placement of the children with disabilities in separated (special) classes in the regular schools is treated as inclusion by many teachers, even though the practice shows that those children either have or do not have minimal contact with the other children.

D The schools are not adequately staffed and equipped to implement the inclusion of children with disabilities in regular primary education. In addition, there is a lack of suitable and continuous trainings for the school teaching staff in working with children with disabilities, and consequently improvement of the quality of education provided to the children with disabilities. In addition, it is also necessary to make the employees more sensitive to the situation of these children and the significance of their inclusion (Ombudsman of the Republic of Macedonia, 2016, p. 50).

\section{Methodology of the research}

\subsection{Goal of the research}

The main goal of this research is to determine the factors that represent a significant barrier for quality inclusive education by examining the attitudes and opinions of all participants who are, in any way, involved in the educational process - parents, teachers, and pedagogical - psychological services, from primary schools in four municipalities in the Republic of Macedonia: Bitola, Prilep, Veles and Valandovo and representatives from the Ministry of Education and Science and the Bureau for Development of Education.

\subsection{Methods and Sample of the research}

Research was conducted with implementation of:

$>$ A questionnaire with 250 parents of children with disabilities and parents of children with typical development, 60 teachers and pedagogical-psychological service department in 10 elementary schools.

$>$ Structured interview with representatives from the Ministry of Education and Science and the Bureau for the Development of Education.

The sample of the research consists of: teachers, parents of children with disabilities, parents of children with typical development, pedagogical-psychological service from 10 primary schools in the Republic of Macedonia and a representative from the Ministry of Education and Science and the Bureau for Development of 
Barriers of educational inclusion of children with disabilities in the elementary education in Macedonia

Education. The sample was chosen randomly in each of the 10 primary inclusive schools from three geographical regions: Southwest region (municipalities Bitola and Prilep), Central Region (municipality Veles) and South-East region (municipality Valandovo).

The questionnaire contained a Likert scale of a series of claims about: the most significant conditions for quality inclusive education; teachers' competences for working with students with disabilities; the advantages and barriers for quality inclusive education. Likert scale determined the degree of agreement or disagreement, on a four-step scale: "I don't agree", "Unspecified", "I agree", "I don't know".

The purpose of the interview is to discuss the views of the representatives from the Ministry of Education and Science and the Bureau for the Development of Education in Republic of Macedonia. The interview contained open-type questions and did not limit representatives in the presentation of views about the quality of inclusive education, the possible barriers and their overcoming.

\subsection{Data processing}

The data were processed quantitatively and qualitatively using the EXCEL and STATISTICS computer programs. The data were grouped according to the number of matching in certain categories and then placed in tables. The data were calculated with frequencies for which a percentage was calculated. In order to popularize certain statistics, they are represented by graphs.

\subsection{Limitations of the Study}

The study examined the attitudes of the teachers, the parents and the pedagogical-psychological service in 10 primary schools in the Republic of Macedonia about barriers of educational inclusion of children with disabilities. The obtained results do not fully reflect the quality of the inclusion in the elementary education in the Republic of Macedonia and should not be generalized in other country. Inclusion is a process by which schools, national and local education authorities and others develop cultures, policies and practices to include students and it is necessary a team approach in detecting and resolving problems in the regular school.

\section{Results}

Inclusive education does not only mean physical accommodation of children with disabilities in the basic school system, it also means inclusion in the work and life of the school. While developing the inclusion process is important, it is also important to develop adequate services that will provide team-approach in resolving problems in the basic public school system. Table 1 presents the attitudes of parents of children with disabilities, parents of children with typical development, teachers and professional associates service for the most significant conditions for improving the quality of inclusive education.

\section{Table 1}

Attitudes on the most significant conditions for implementing inclusive education

\begin{tabular}{|c|c|c|c|c|}
\hline & $\begin{array}{c}\text { Professional } \\
\text { associates } \\
(\%)\end{array}$ & $\begin{array}{l}\text { Teachers } \\
(\%)\end{array}$ & $\begin{array}{l}\text { Parents of children } \\
\text { with typical } \\
\text { development }(\%)\end{array}$ & $\begin{array}{c}\text { Parents of } \\
\text { children with } \\
\text { disability }(\%)\end{array}$ \\
\hline $\begin{array}{l}\text { Children with disabilities to receive educational } \\
\text { assistants from the state }\end{array}$ & 84.6 & 83.5 & 78.8 & 80 \\
\hline $\begin{array}{l}\text { Accessibility for children with physical } \\
\text { disabilities - ramps, elevators, adapted toilets }\end{array}$ & 76.9 & 90 & 76 & 82 \\
\hline Didactic materials for inclusive teaching & 69.24 & 91.6 & 74 & 81 \\
\hline Cooperation of teachers with parents & 61.24 & 91.6 & 70.7 & 87 \\
\hline Less number of students in class & 84.6 & 86.7 & 64.7 & 74 \\
\hline $\begin{array}{l}\text { Collaboration of teachers with professional } \\
\text { associates }\end{array}$ & 53.85 & 86.7 & 67 & 85 \\
\hline Additional education and training of teachers & 61.54 & 75 & 57.3 & 80 \\
\hline
\end{tabular}


According to the results, most of the respondents agree that the most important conditions for realization of quality inclusive education are:

$>$ Educational assistants from the state are to work with children with disabilities should receive $(84.6 \%$ of professional associates, $83.5 \%$ of teachers, $78.8 \%$ of parents of children with typical development, and $80 \%$ of parents with children with disabilities);

$>$ Accessibility for children with physical disabilities - ramps, elevators, adapted toilets $(76.9 \%$ of professional associates, $90 \%$ of teachers, $76 \%$ of parents of children with typical development, and $82 \%$ of parents with children with special needs);

$>$ Didactic materials for inclusive teaching $(69.24 \%$ of professional associates, $91.6 \%$ of teachers, $74 \%$ of parents of children with typical development, and $81 \%$ of parents with children with special needs);

$>$ Cooperation between the teachers and the parents $(69.24 \%$ of professional associates, $91.6 \%$ of teachers, $70.7 \%$ of parents of children with typical development, and $87 \%$ of parents of children with special needs);

$>$ Decreased number of students in one classroom (84.6\% of the professional associates, $86.7 \%$ of the teachers, $64.7 \%$ of the parents of children with typical development, and $74 \%$ of the parents of children with special needs);

$>$ Collaboration between the teachers and the with professional associates $(53.85 \%$ of professional associates, $86.7 \%$ of teachers, $67 \%$ of parents of children with typical development, and $85 \%$ of parents of children with disabilities);

$>$ Additional education for teachers (61.54\% of professional associates $75 \%$ of teachers, $57.3 \%$ of parents of children with typical development, and $80 \%$ of parents of children with disabilities).

Representative of the Ministry of Education and Science was asked what needs to be done in order to improve the quality of inclusive education:

$>$ Application of all forms, methods and activities for raising awareness and sensitization of all participants who are in any way involved in the educational process (teachers, professional associates, parents of children with typical development, parents of children with special educational needs , students and the general public);

> Full implementation of the existing Articles of the Law on Primary Education and the Law on Secondary Education, which regulate inclusive education.

D Equipping functional inclusive teams with appropriate professional associates (pedagogue, psychologist and special educator).

$>$ Increasing the inventiveness, creativity and motivation of the teaching staff that works with children with special needs.

$>$ Intensifying the cooperation with parents, and encouraging their inclusive involvement in supporting students and school activities.

$>$ Full implementation of the available didactic tools.

$>$ Functional system for assessing and monitoring children at risk.

D Increasing the inclusion of children with disabilities in kindergartens and day care centers for early childhood development. 
The start of inclusive education calls for changes in the curriculum, teachers' education, teaching methodology and teachers' attitudes. If the teachers are expected to teach children with a wide range of abilities and developmental difficulties, then additional adaptations and complementation of their education are needed and should be implemented. A number of research has been carried out and it proved that the attitude of teachers towards children with disabilities depends on the personality of the teacher, his competences, formal and non-formal education (Rajovic, 2010; Dizdarević, 2017; Avramidis, 2002).

Table 2 presents the attitudes of teachers and parents regarding the competencies of teachers for working with children with disabilities.

Table 2

Teachers have enough competencies to work with children with disabilities

\begin{tabular}{lcccc}
\hline & Don't agree & Undetermined & \multirow{2}{*}{ Agree $(\%)$} & Don't know \\
& $(\%)$ & $(\%)$ & 16.7 & 3.3 \\
\hline Teachers & 66.6 & 13.4 & 22.7 & 19.3 \\
Parents of children with typical development & 29 & 26 & 22 & 6 \\
Parents of children with disabilities & 46 & 22 & & 6 \\
\hline
\end{tabular}

Most of the teachers $(66.6 \%)$ agree that they don't have sufficient competences for working with children with disabilities, because in their formal education there have been no materials and study subjects for this particular topic. They have also stated that they need additional trainings and seminars in the field of educational inclusion in order to gain the much needed knowledge. The majority of parents of children with disabilities $46 \%$ also agree that teachers need additional training to improve their competences. The parents of children with typical development have divided opinions: $29 \%$ disagree, $28.7 \%$ agree, $22 \%$ are undetermined and $19.3 \%$ do not know if teachers have enough competencies to work with children with different needs.

Table 3 illustrates some opinions on the quality of the process of teaching children with disabilities in the basic educational system. On this matter, the teachers have given their views on classes' practical realization that calls for measures such as: the need for additional training, the preparation of an Individual education plan, the cooperation with the parents and the pedagogical-psychological service department, and the specific teacher-student and student - student relationship.

Table 3

Claims for the quality of the process of teaching children with disabilities in the basic educational system

\begin{tabular}{|c|c|c|c|c|}
\hline & $\begin{array}{l}\text { Don't agree } \\
(\%)\end{array}$ & $\begin{array}{l}\text { Undetermined } \\
(\%)\end{array}$ & Agree $(\%)$ & $\begin{array}{c}\text { Don't know } \\
(\%)\end{array}$ \\
\hline $\begin{array}{l}\text { When in the class there is a child with } \\
\text { disabilities, I try to sensitize the children with } \\
\text { typical development, but also and their parents }\end{array}$ & 1.6 & 11.7 & 65 & 21.7 \\
\hline $\begin{array}{l}\text { Cooperation with parent is great importance } \\
\text { and assistance, especially for children with } \\
\text { disabilities }\end{array}$ & 0 & 0 & 79.3 & 20.7 \\
\hline $\begin{array}{l}\text { A large number of seminars and trainings for } \\
\text { inclusive teaching is very important }\end{array}$ & 3.3 & 3.3 & 73.4 & 20 \\
\hline $\begin{array}{l}\text { I implement differentiated instruction according } \\
\text { to the possibilities of each student }\end{array}$ & 3.4 & 21.7 & 59.9 & 15 \\
\hline $\begin{array}{l}\text { The cooperation between the inclusion team } \\
\text { and the parents facilitates the process of } \\
\text { transition from the class teaching to the subject } \\
\text { teaching }\end{array}$ & 3.3 & 16.7 & 63.3 & 16.7 \\
\hline $\begin{array}{l}\text { Inclusion team, pedagogical-psychological } \\
\text { service and parents are involved in the } \\
\text { development of individual educational plan }\end{array}$ & 3.5 & 16.6 & 58.3 & 21.6 \\
\hline $\begin{array}{l}\text { For children with disabilities, I prepare an } \\
\text { individual education plan }\end{array}$ & 6.7 & 15 & 58.3 & 20 \\
\hline
\end{tabular}


Most of the teachers have positive attitudes i.e. they agree with the following claims:

$>$ If there is a child with disabilities in the class, I try to sensitize the children with typical development, but also and their parents $(65 \%)$;

$>$ Cooperation with parents is of great importance and assistance, especially for children with disabilities $(79.3 \%)$,

$>$ A large number of seminars and trainings for inclusive teaching are needed $(73.4 \%)$,

$>\quad$ I implement customized instruction according to the possibilities of each student $(59.9 \%)$;

$>\quad$ The cooperation between the inclusion team and the parents makes the transition from elementary teaching to the subject-specific teaching easier $(63.3 \%)$;

$>\quad$ The inclusion team, the pedagogical- psychological service, and parents $(58.3 \%)$ are all involved in the development of an Individual Education Plan;

$>\quad$ I prepare an Individual Education Plan for children with disabilities (58.3\%)

Teachers must have the support they need to educate all children in their classes. This support may be needed in the form of extra planning time, educational assistants, specific training in teaching methods or learning styles or even environmental aids, such as appropriate desks and other physical materials for students. All students can benefit from a variety of learning styles and teaching methods being utilized in the classroom.

Open communication and coordinated planning between teachers, pedagogical- psychological service, and special education staff are essential for inclusion to work. Time is needed for teachers and specialists to meet and create well-constructed plans to identify and implement modifications the, accommodations, and specific goals for individual students.

The three groups of respondents (parents of children with typical development and disabilities, teachers and staff in the psychological-pedagogical service) were asked what are the advantages and barriers for inclusive education. The comparative analysis of the results of the responses showed the following advantages and barriers of inclusive education.

\section{Advantages of inclusive education:}

$>$ Inclusive education helps in developing: empathy, altruism, humanity, respect for diversity and acceptance of every child;

$>\quad$ Contributes to the socialization of all children;

$>$ Develops a sense of equality and belonging, helps overcome stereotypes, prejudices and discrimination.

\section{Barriers for inclusive education:}

$>\quad$ Lack of adequate staff and technical conditions for improving the quality of inclusive education;

$>$ Lack of education, training and motivation of the teaching staff and psychological-pedagogical service;

$>\quad$ Lack of education for both parents of children with typical development and parents of children with disabilities;

According to the representative of the Bureau for Development of Education, the main barriers / obstacles to 
Barriers of educational inclusion of children with disabilities in the elementary education in Macedonia

quality inclusive education are:

$>\quad$ Insufficient capacity for raising awareness about the importance and the need for promoting inclusive education.

$>\quad$ Slow removal of physical barriers.

$>\quad$ Lack of a strategy for inclusive education in Republic of Macedonia.

$>\quad$ Lack of a comprehensive legal framework that treats inclusive education.

$>$ A small number of schools have complete inclusive teams, with the necessary professional associates (pedagogue, psychologist and special educator).

$>\quad$ Poorly trained teaching staff.

$>$ Poorly informed parents.

$>\quad$ Lack of sensibility to the subject by students with typical development.

$>\quad$ Lack of special didactic means.

$>\quad$ A system for assessing and monitoring children at risk that lacks efficiency

$>\quad$ Low inclusion of children with disabilities in kindergartens and day care centers for early childhood development.

Most respondents agree that inclusive education develops empathy, altruism, humanity promotes respecting diversity and accepting every child; contributes to greater socialization of every child, not only of children with disabilities; and helps to overcome stereotypes, prejudices and discrimination.

Upon assessing the quality of inclusive education, all respondents agree that there are numerous barriers that reduce its quality. The lack of adequate staff and technical conditions contribute to the development of a negative attitude towards the inclusive model of education. Furthermore, the lack of education, training and motivation of the teaching staff and psychological-pedagogical service, as well as lack of education for both parents of children with typical development and parents of children with disabilities. All of these factors can be considered a barrier for quality inclusive education.

\section{Conclusions and recommendations}

Upon analyzing the results of the obtained data, we can conclude that there are numerous barriers to inclusive education that are quite common and which were stressed by the representatives of institutions, teachers as well as parents.

Creating better staffing and technical conditions for improving the quality of inclusive education is one of the main barriers to quality inclusive education. The schools should provide conditions for enrolling the children with disabilities in regular education, in accordance with their needs, whereupon every child will receive the needed assistance in the education process. Thus, a change is called upon: inclusive teams are to be created in all schools, the number of students in classes that include students with disabilities is to be reducing, better didactic materials and assistive technology are to be provided, accessibility is to be improving and educational and/or personal assistants for each child with disabilities are to be provided, according to the individual needs. This approach and the aforementioned changes are the only way in which the educational inclusion can be resumed on the right track. In order for educational reforms to be effective, implementers must provide opportunities for active participation of all stakeholders in the design, implementation, and monitoring/evaluation of reforms. 
While developing the inclusion process is important, it is also important to develop adequate services that will provide team-approach in resolving problems in the basic public school system, take action for networking and strengthening the capacities of the existing institutions that are included in the support of the children with disabilities (centers for social work, schools, health care institutions, local government) in order to have an unhindered and effective approach to achieving the rights of the children with disabilities.

It is also fundamental to provide appropriate training for teachers in order for them to acquire basic, necessary knowledge for recognizing the children with special educational needs and providing adequate assistance; also, to include a special educator in the school, as well as to provide specialized means in line with the difficulties that the students face. These include: appropriate equipment, instructional means and customized, adapted space.

Another barrier for quality inclusive education is the need for education, training and motivation of the teaching staff and the psychological and pedagogical service in the schools. The teaching staff and the staff in the psychological-pedagogical service department in the primary schools constantly face various challenges with students with disabilities - challenges that they have little to no knowledge on how to resolve. And although there are some teachers who continue with self-education (formal or non formal education) and strive to stay self-motivated, in order to achieve more with their students with disabilities; truth is, that the only right way to solve this issue would be to provide subjects and contents related to inclusive education in the teachers' formal education. As education is a continuous, life-long process, continuous education and training must be provided for the teaching staff. The competent bodies (Ministry of Education and Science and the Bureau for Development of Education, schools) to plan continuous and adequate trainings, in order to make the entire teaching staff more sensitive to working with children with disabilities through the prism and concept of children's rights and in that regard, educate the teachers and encourage their self-initiative, creativity and improve their capacities to work with children with disabilities.

Creating a network that will enforce mutual assistance and support between the teachers and professional associates (psychologists, pedagogues, speech therapists and special educators) at the national and local level can also be of great importance for the work of the teaching staff.

The third barrier points to the need to educate the parents of the children with a typical development in order to raise awareness for the rights of children with disabilities, as equal members of society; and accepting children with special needs in order to overcome prejudice, stereotypes and discrimination. It is also necessary to educate the parents of the children with disabilities for their rights, their children's rights in the field of education, as well as the procedures and mechanisms for exercising their rights. Inclusive education in the Republic of Macedonia started not long ago in elementary education, with parallel adoption of laws and rulebooks necessary for its implementation and training of teachers and other professional staff. Parents of children with disabilities are not fully informed about their children's rights in the field of education, as well as the procedures and mechanisms for exercising those rights. Effective communication and partnership between parents and school staff can increase creativity and help to make the best use of resources; however parents are the ones who have the most experience and they are the ones who best know their own child.

\subsection{Recommendations for teachers}

$>$ Create an inclusive team in the school and collaborate with each other.

$>$ Communicate with other teachers who have experience in working with students with disability. Their advice can be of great help and support in a given situation.

$>\quad$ You are a model for your students, they learn from your behavior. So be calm, patient, kind, show empathy, practice communication based on respect and understanding. 
Barriers of educational inclusion of children with disabilities in the elementary education in Macedonia

$>$ Encourage and praise students.

$>$ Provide a pleasant atmosphere for working at the class. Be prepared for behavioral changes that the student can manifest during the class.

Identify, anticipate, and have a strategy to deal with situations that can cause changes in the mood and frustrations of a student.

Always strive to tailor tasks and activities according to the needs and abilities of the student.

$>$ Share the information in different ways.

$>$ Give directions in a language that the student can understand. Whenever necessary, use visual signs (practical demonstrations and models, objects, images) to help the student better understand the given directions.

$>$ Avoid completing sentences instead of a student who can't be expressed.

> Monitor your student's progress regularly and give him constructive feedback on what he has been doing. Lead the student through questions through his performance to see how he understands what he is learning.

> Make parents partners in the student's education Keep in mind that from parents you can learn a lot, not just for their child but also for other children with disability, and share information you may not be able to find in any one literature.

\subsection{Implications}

The findings of this study enabled to present some implications that might be useful for policy makers, teachers, and educational researchers.

The improvement of the staffing and technical conditions is a prerequisite for improving the quality of inclusive education itself; it is, in fact, an issue that should have been resolved systematically before the start of the inclusive processes development. If policy makers and institutions provide and create conditions in which all citizens can achieve their rights, will develop a society without discrimination, a society that gives everyone an opportunity; that will have a positive impact in diverse ways for social and national development.

Creation of infrastructural accessibility, available materials and resources will enable overcoming stereotypes and improving the public awareness that these citizens are not "specials" and have equal rights.

The modest effects of reform changes in teachers' attitudes toward inclusive education can be seen as a result of top-down approach in the implementation process.

Another systemic barrier to implementing successful inclusive education is lack of resources available to teachers. The term 'resources' refers not only to teaching methods and materials but also to time available for instruction, professional support, and to teachers' knowledge and skills acquired through training and experience. Generally, a shortage of these resources can be overcome in two ways: by an increase in/creating resource (e.g. financial support for purchasing education-related ICT equipment and investment in human resources) or by re-arranging available resources (e.g. team work of special educators and general education teachers).

The main reason why teachers disregard inclusion is self-perception that they do not have enough competence to teach students with disability. Teachers' knowledge and beliefs are filters through which their practices, strategies, actions, interpretations and decisions are made. A greater variety of activities, both formal and informal, designed to improve the knowledge, skills, and commitments of teachers should be provided. At the same time, more attention should be given to the quality of professional development programs which are 
offered.

Most of parents and teachers accept attitudes towards inclusion in accordance with the human principle, agree that inclusion develop empathy, altruism, respect for differences and acceptance of every child; socialization of children and development of humanity; overcoming the stereotypes, prejudices and discrimination. These attitudes are only at the declarative level or indeed are authentic part of their personal value system which they reflect and develop with their children is area for new researches.

Acknowledgement -This research was conducted with the financial support of the Foundation Open Society Macedonia (FOOM) and approved by the Ministry of Education and Science of the Republic of Macedonia.

\section{References}

Armstrong, F. (2003). Spaced out: Policy, difference and the challenge of inclusive education. Dordrecht: Kluwer Academic Publishers.

Avramidis, E., \& Norwich, B. (2002). Teachers' attitudes towards integration / inclusion: a review of the literature. European Journal of Special Needs Education, 17(2), 129-147. https://doi.org/10.1080/08856250210129056

Bartolo, P. (2004). Recent developments in inclusive education in Malta. Mediterranean Journal of Educational Studies, 6(2), 65-91.

Dizdarević, A., Mujezinović, A., \& Memisević, H. (2017). Comparacion of teachers' attitudes toward inclusive education in Bosnia and Herzegovina and Europion Union. Journal of special education and rehabilitation, 18(1-2), 92-108. https://doi.org/10.19057/jser.2017.21

Lambert, N., \& McCombs, B. (1998). How students learn: reforming schools through learner-centered education. Washington, D.C: American Psychological Association. https://doi.org/10.1037/10258-000

Ministry of Education and Science. (2010). Inkluzivno obrazovanie vo ramkite na ucilišta po merka na deteto: rezultati I preporaki od studijata za Makedonija [Inclusive education within schools by measure of the child: results and recommendations from the study on Macedonia], Skopje: Ministry of Education and Science of the Republic of Macedonia. Retrieved from https://www.unicef.org/tfyrmacedonia/INCLUSIVE_REPORT_MKD.pdf

Ministry of Education and Science. (2018). Zakon za osnovno obrazovanie [Law for elementary education], Skopje: Ministry of Education and Science of the Republic of Macedonia, Retrieved from http://www.sonk.org.mk/documents/Zakon\%20za\%20osnovno\%20obrazovanie.pdf

Ombudsman of Republic of Macedonia. (2016). Kon inkluzivno obrazovanie - Извештај од истражување за вклученост на децата со посебни потреби во редовното основно образование [Towards inclusive education - Report of the conducted research regarding inclusion of children with disabilities in regular primary education], Skopje: UNICEF. Retrieved from https://www.unicef.org/tfyrmacedonia/macedonian/resources.html

Rajović, V., \& Jovanović, O. (2010). Profesionalno i privatno iskustvo sa osobama s posebnim potrebama i stavovi nastavnika redovnih škola prema inkluziji [Professional and private experience with people with special needs and attitudes of regular school teachers towards inclusion]. Psihološka istraživanja 8(1), 91-106. https://doi.org/10.5937/PsIstra1001091R

Smith, P. (2007). Have We Made Any Progress? Including students with intellectual disabilities in regular education classrooms. Intellectual and Developmental Disabilities, 45(5), 297-309. https://doi.org/10.1352/0047-6765(2007)45[297:HWMAPI]2.0.CO;2

Steinbeck, J. (1952). East of Eden. New York: Penguin. 